\title{
PERFORMANCE OF GROWING RABBITS FED GRADED LEVELS OF GOAT RUMEN CONTENT.
}

\author{
G. MOHAMMED, J. U. IGWEBUIKE and I. D. KWARI \\ (Received 21 June 2004; Revision Accepted 27 August 2004)
}

\begin{abstract}
A ten-week feeding trial was conducted to assess the biological and economic performance of growing rabbits fed graded levels of goat rumen content (GRC). The GRC which contained $27.25 \%$ crude protein and $28.33 \%$ crude fibre were included at $0,10,20,30$, and $40 \%$ levels in diets $1,2,3,4$ and 5 respectively to replace maize and groundnut cake in the diets. Thirty crossbred rabbits (Dutch X New Zealand White) between 5 and 7 weeks of age were randomly allocated to the 5 dietary treatments in groups of 6 and allowed unlimited access to the feed and drinking water throughout the experimental period. The daily feed intake (FI) were 49.0,50.08,51.05, 49.05 and $50.77 \mathrm{~g}$ for diets 1 (control), 2, 3, 4' ands 5 respectively. The corresponding daily weight gains (DWG) were 11.07, $10.0,9.52,8.96$ and $8.69 \mathrm{~g}$. The FI, DWG and feed conversion ratio did not significantly $(p>0.05)$ differ among the treatments. The feed cost per $\mathrm{kg}$ decreased as the level of GRC increased in the diets. The feed per $\mathrm{kg}$ of weight gain also steadily declined from $20 \%$ to $40 \%$ levels of GRC hence leading to lowered feed cost and cost of production Therefore, $40 \%$ GRC could be incorporated into the diets of growing rabbits without adverse effects on performance.
\end{abstract}

KEY WORDS: Growing Rabbits; Performance; Goat rumen content.

\section{INTRODUCTION}

The need to closely examine the usefulness of minilivestock such as rabbits as sources of animal protein has been advocated (Ebenebe, 2000). The greatest potential for the use of meat rabbit is in those countries experiencing national animal protein shortages (Owen, 1981).

Rabbits are fast-growing, prolific and are known to be highly efficient in converting diverse plant materials into meat (Spedding et al., 1976; Cheeke et al., 1982) Rabbit meat has high protein but low fat, sodium and cholesterol levels (Rao et al., 1978).

Despite the proven better performance of rabbits on pelleted feed (McNitt, 1980; Cheeke et al., 1982; Harris et al., 1983), rabbit farmers in Nigeria still resort to the use of unpelleted feed due to the scarcity and exorbitant cost of the pelieted ones. Poultry growers' mash and other sundry feeds have been fed to rabbits (Spreadbury, 1978; Ekpenyong; 1984).

The abundance of rumen content which presents problems in many abattoirs and slaughter houses in Nigeria may provide the needed alternative for feeding rabbits at cheaper cost. Preliminary studies by Egege (1994) and Ibeawuchi and Gbue (1995) have highlighted the possibility of adapting bovine rumen content as a suitable feed ingredient for growing rabbits. The study reported here examined the performance of growing rabbits fed graded levels of goat rumen content (GRC). It is envisaged that the widespread use of rumen content for animal feeding will enhance the disposal of this waste from the abattoirs.

\section{MATERIALS AND METHODS}

\begin{abstract}
Study Location
The study was conducted in Maiduguri which is located in the semi-arid area of north eastern Nigeria. The area is characterized by short rainy season $(3-4$ months) and very long dry season ( 8 - 9 months). Mean ambient temperature is $31^{\circ} \mathrm{C}$ by August but gets as high as $40^{\circ} \mathrm{C}$ or more by April to May (Alaku and Moruppa, 1988)
\end{abstract}

\section{Management of the experimentai stock \\ Thirty (30) crossbred rabbits fDutch $\times$ New Zealand White) of mixed sexes, age ranging from $5-7$ weeks, were randomly allocated to five treatments in groups of 6 rabbits each. The rabbits were housed individually in cages measuring $35 \mathrm{~cm} \times 36 \mathrm{~cm} \times 45 \mathrm{~cm}$ (width $x$ length $x$ height) and supplied daily with the experimental diets, in mash form, and clean drinking water ad libitum throughout the experimental period of 10 weeks.}

\section{Experimental diets \\ The experimental diets (Table l) were compounded using maize, maize bran, goat rumen content, groundnut haulms (hay), fish meal, salt and premix. The diets contained $0,10,20,30$ and $40 \%$ of goat rumen content (GRC) in diets 1 (control), 2, 3, 4 and 5 respectively. The diets supplied approximately $21 \%$ crude protein.}




\section{Source of goat rumen content (GRC)}

Wet goat rumen content (GRC) was collected from fresh heaps within the premises of Maiduguri abattoir, Borno State, Nigeria. The GRC was spread and sun-dried on concrete floor at the abattoir. The dry goat rumen content was ground using a hammer mill before inclusion into the diets at the specified levels.

\section{Data collection}

The daily feed intake was obtained by subtracting the left over from the total amount of feed supplied. Each rabbit was weighed at the inception of the experimental and weekly thereafter to obtain the weekly and daily body weight gain throughout the experimental period. The feed conversion ratio was calcuiated as the dry matter feed intake per unit weight gain.

The economic implication of including GRC into the diets of growing rabbits was assessed by calculating the:-

1. Cost per kilograms of each diet;

11. Cost of feeding the rabbits on their respective diets throughout the experimental period; and

III. Cost per kilogram of weight gain by the rabbits.

\section{Chemical and statistical analyses}

The proximate analysis of the experimental diets and GRC was carried out according to AOAC (1980) methods. Analysis of variance (ANOVA) was carried out on the data collected (Steel and Torrie, 1980) and means separated, where applicable, using the Duncan's multiple range test (Duncan, 1955).

\section{RESULTS AND DISCUSSION}

\section{Proximate analysis of the diets and goat rumen content}

The chemical composition of the experimental diets is shown in Table 2. The crude protein contents of the diets are adequate for growing rabbits. Omole (1982) recommended protein level of $18 \%$ for growing rabbits reared in tropical countries. However, the quality of dietary protein is very important in rabbit nutrition since voluntary feed has been found to increase with improvement in protein quality (Kennedy and Hersherger, 1974; Spreadbury, 1974). The crude fibre levels of the diets increased with increasing level of goat rumen content (GRC) in the diets. This may be attributed to the higher crude fibre content of GRC compared to maize and groundnut cake (GNC). The fibre levels of the diets $(18.50-24.50 \%)$ were higher than the $14 \%$ recommended by Anugwa et al. (1982) for growing rabbits but close to the 15.0 to $20 \%$ recommended by Cheeke et al. (1982). Fat levels which ranged from 3 to $5 \%$ are adequate; Cheeke (1974) reported that a minimum level of $3 \%$ fat is ideal to provide essential fatty acids and maintain glossy sleek hair.

The metabolizable energy levels of the diets containing GRC are lower than that of the control $10 \%$ $G R C$ ). This may be due to the lower energy level $(2369.60 \mathrm{Kcal} / \mathrm{kg})$ of GRC compared to the energy levels of 3730.0 and $2891 \mathrm{Kcal} / \mathrm{kg}$ respectively for maize ancl GNC (Gohl, 1981).

TABLE 1: COMPOSITION OF THE EXPERIMENTAL DIETS

\begin{tabular}{|l|l|l|l|l|l|}
\hline Ingredient (\%) & \multicolumn{5}{|c|}{ Diets } \\
\cline { 2 - 6 } & 1 & 2 & 3 & 4 & 5 \\
\hline Maize & 40.98 & 36.35 & 32.48 & 28.25 & 23.98 \\
\hline Maize offal & 17.00 & 17.00 & 17.00 & 17.00 & 17.00 \\
\hline Groat rumen content & 0.00 & 10.00 & 20.00 & 30.00 & 40.00 \\
\hline Groundnut cake & 13.00 & 13.00 & 13.00 & 13.00 & 13.00 \\
\hline Fish meal & 23.37 & 17.60 & 11.87 & 6.10 & 0.37 \\
\hline Bone meal & 3.00 & 3.00 & 3.00 & 3.00 & 3.00 \\
\hline Salt (NaCl) & 2.00 & 2.00 & 2.00 & 2.00 & 2.00 \\
\hline Premix* & 0.50 & 0.50 & 0.50 & 0.50 & 0.50 \\
\hline Total & 0.15 & 0.15 & 0.15 & 0.15 & 0.15 \\
\hline
\end{tabular}

* Composition of premix (Bio - Mix) Supplying following per $\mathrm{kg}$ diet: Vitamin $A, 5,000,001 \mathrm{U}$, vitamin $D_{3} 800,000 \mathrm{IU}$, vitarnin $E 12,000 \mathrm{mg}$; vitamin $K$ $1,5000 \mathrm{mg}$, vitamin $B_{1} 1,000 \mathrm{mg}$, vitamin $B_{2} 2,000 \mathrm{mg}$, vitamin $B_{6} 1,5000 \mathrm{mg}$; Niacin $12,000 \mathrm{mg}$; Pantothenic acid $20.00 \mathrm{mg}$ Biotin $10.00 \mathrm{mg}$; vitamin $B_{12}$ $300.00 \mathrm{mg}$; folic acid $150,000 \mathrm{mg}$; choline chloride $60,000 \mathrm{mg}$; manganese $10,000 \mathrm{mg}$; iron $15,000 \mathrm{mg}$; zinc $800.00 \mathrm{mg}$; copper $400.00 \mathrm{mg}$; iodine $80.00 \mathrm{mg}$; cobalt $40 \mathrm{mg}$; selenium $8,000 \mathrm{mg}$. 
TABLE 2: $\quad$ PROXIMATE COMPOSITION OF THE EXPERIMENTAL DIETS AND GOAT RUMEN

\begin{tabular}{|c|c|c|c|c|c|c|}
\hline \multirow[t]{2}{*}{ Nutrient $(\%)^{\top}$} & \multicolumn{6}{|c|}{ Treatments/Diets } \\
\hline & 1 & 2 & 3 & 4 & 5 & $\begin{array}{l}\text { Goat rumen } \\
\text { content }\end{array}$ \\
\hline Dry matter (DM) & 99.97 & 99.98 & 99.97 & 99.97 & 99.98 & 99.97 \\
\hline Crude protein (CP) & 21.11 & 20.69 & 20.89 & 20.93 & 20.51 & 27.25 \\
\hline Crude fibre (CF) & 18.5 & 20.5 & 21.25 & 23.5 & 24.5 & 28.33 \\
\hline Ether extract (EE) & 5.5 & 3.5 & $4: 0$ & 5.0 & 5.0 & 4.33 \\
\hline Ash & 6.5 & 10.5 & 11.0 & 14.0 & 15.0 & 11.50 \\
\hline Nitrogen-free extract (NFE) & 48.39 & 44.81 & 42.86 & 36.57 & 34.99 & 28.59 \\
\hline Metabolisable Energy (Kcal $/ \mathrm{kg})^{2}$ & 2944.41 & 2639.79 & 2618.46 & 2477.65 & 2406.02 & 2373.93 \\
\hline
\end{tabular}

1. Mean of 3 determinations

2. Calculated according to the formula of Pauzenga (1985):

$\mathrm{ME}(\mathrm{Kcal} / \mathrm{kg})=37 \times \% \mathrm{CP}+81 \times \% \mathrm{EE}+35.5 \times \%$ NFE.

TABLE 3: PERFORMANCE OF RABBITS FED DIFFERENT LEVELS OF GOAT RUMEN CONTENT

\begin{tabular}{|l|l|l|l|l|l|l|l|}
\hline \multirow{2}{*}{ Parameters } & \multicolumn{6}{|c|}{ Treatments/Diets } \\
\cline { 2 - 8 } & 1 & 2 & 3 & 4 & 5 & Mean & SEM \\
\hline Initial weight (g/rabbit) & 525.0 & 1225.0 & 525.0 & 523.0 & 525.0 & 524.6 & $41.39^{\text {NS }}$ \\
\hline Final live weight (g/rabbit) & 1300.00 & 125.00 & 1191.67 & 1150.00 & 1133.33 & 1200.00 & $75.0^{\text {NS }}$ \\
\hline Mean daily weight gain (g/rabbits) & 11.07 & 10.00 & 9.52 & 8.96 & 8.69 & 9.65 & $0.49^{\text {NS }}$ \\
\hline Mean daily feed intake (g/rabbit) & 49.02 & 50.08 & 51.05 & 49.05 & 50.77 & 49.99 & $0.62^{\text {NS }}$ \\
\hline Feed conversion ratio (FCR) & 4.23 & 5.01 & 5.36 & 5.47 & 5.84 & 5.18 & $0.43^{\text {NS }}$ \\
\hline Mortality & Nil & Nil & Nil & Nil & Nil & - & - \\
\hline
\end{tabular}

* $F C R=$ feed intake/weight gain

SEM - Standard error of means

NS - Not significant $(p>0.05)$

The chemical composition of GRC presented here (Table 2) tallies with the findings of Ghol (1981) who reported that ovine (sheep) rumen content is composed of $28.0 \%$ crude protein, $25.5 \%$ crude fibre, $4.6 \%$ fat, $12.30 \%$ ash and $28.8 \%$ nitrogen-fibre extract.

\section{Performance characteristics}

Results of performance parameters are presented in Table 3. There were no significant ( $p>0.05$ ) differences in mean feed intake, body weight gain and feed conversion ratio among the treatments. The results indicate that up to $40 \%$ inclusion of goat rumen content into the diets of growing rabbits has no adverse effects on feed intake ( $F I)$, weight gain (WG) and feed conversion ratio (FCR). The values of (FI), WG and FCR reported in this study compare favourably with results obtained in similar studies (Egege, 1994; Ibeawuchi and Gbue, 1995) in which graded levels of dried rumen content were incorporated into the diets of young rabbits. The slight variation in mean daily weight gain (10 - 15g/rabbit/day) reported by Olumeyan et al. (1995) could be attributed to the micro-climatic conditions at the experimental site. During the experimental period, ambient temperature ranged from $36^{\circ} \mathrm{C}$ to $41^{\circ} \mathrm{C}$ and this is above the comfort zone $116^{\circ} \mathrm{C}$ to $19^{\circ} \mathrm{C}$ ) of rabbits beyond which feed intake and weight gain are adversely affected (Fielding, 1991).

\section{Economic analysis}

The economic performance presented in Table 4 showed that cost per kilogram of feed decreased steadily as the level of goat rumen content (GRC) increased in the diets. The feed cost per $\mathrm{kg}$ of weight gain also steadily declined from $20 \%$ to $40 \%$ levels of goat rumen content (GRC) in the diets. Increasing the quantity of GRC in the diets resulted in the reduction of the quantity of maize and groundnut cake in the diets. These ingredients are more expensive than goat rumen content as shown in Table 4. Thus, incorporation of GRC into the diets of growing rabbits lowered the feed 
TABLE 4: ECONOMIC PERFORMANCE OF RABBITS FED DIFFERENT LEVELS OF GOAT RUMEN CONTENT

\begin{tabular}{|l|l|l|l|l|l|}
\hline \multirow{2}{*}{ Parameters } & \multicolumn{5}{|c|}{ Treatments/Diets } \\
\hline & 1 & 2 & 3 & 4 & 5 \\
\cline { 2 - 7 } & 0 & 10 & 20 & 30 & 40 \\
\hline Initial weight (g/rabbit) & 525.00 & 525.00 & 525.00 & 523.00 & 525.00 \\
\hline Final live weight (g/rabbit) & 1300.00 & 1225.00 & 1191.67 & 115.00 & 1133.33 \\
\hline Total feed intake/rabbit (g) & 2059.0 & 2078.0 & 2144.0 & 2060.0 & 2145.0 \\
\hline Total feed intake/rabbit $(\mathrm{kg})$ & 2.059 & 2.078 & 2.144 & 2.060 & 2.145 \\
\hline Cost/kg fed (N) & 27.08 & 24.65 & 22.22 & 18.60 & 16.16 \\
\hline Total weight gain/rabbit (g) & 775.00 & 700.00 & 666.67 & 627.00 & 608.33 \\
\hline Total weight gain/rabbit $(\mathrm{kg})$ & 0.78 & 0.70 & 0.67 & 0.63 & 0.61 \\
\hline Cost/kg gain (N/kg) & 71.47 & 73.17 & 71.10 & 60.83 & 56.69 \\
\hline
\end{tabular}

Cost per kilogram of the various ingredients used in compounding the experimental diets: Goat rumen content, $N 5.00$; maize, $N$ 33.75; maize offals, 10.00 ; groundnut cake, $N 26.00$; groundnut haulm $N 20.00$; fish meal, $N 60.00$; bone meal, $N 20.00$; salt, $N$ 15.00 and premix, $N 400.00$. One US Dollar $(\$)=\$ 138.00$ (Nigerian currency)

cost and hence cost of production.

\section{CONCLUSION}

The results of this study indicate that up to $40 \%$ GRC could be incorporated into the diets of growing rabbits without adverse effects on the performance of the rabbits. Additional advantages are reduced feed cost and lower cost per $\mathrm{kg}$ weight gain observed on the GRC - based diets. These are incentives that could warrant the recommendation of GRC as a dietary component for growing rabbits. However, further studies are needed to evaluate the effect of GRC on nutrient digestibility, blood components and the histopathology of the digestive tract which could be used to assess the health status of growing rabbits

\section{REFERENCES}

Alaku, S. O. and Moruppa, S. M., 1988. Organ weight losses in goats during the long dry season in the Sahel Region of West Africa. J. Arid. Agric. 1: $23-35$

Anugwa, F. O. I. Okorie, A. U. and Esomonu, A. F. N., 1982. Feed utilization and growth of rabbits fed three levels of protein and energy. Nig. J. Sci. $3(2): 109-114$

AOAC, 1980. Official Methods of Analysis of Official Analytical chemists. $13^{\text {th }}$ ed. Association of Official Analytical Chemists, Washington, DC. Pp. 1018.

Cheeke, P.R., 1974. Feed preference of adult male Dutch rabbits. Lab. Anim. Sci. 24: $601-604$.

Cheeke, P. R., Patton, N. M. and Templeton, G. S., 1982. Rabbit Production. The Interstate
Publishers and Printers Inc. Danville, Illinois USA.

Duncan, D. B., 1955. Multiple range and multiple Ftests. Biometrics 11: 1- 42

Ebenebe, C. 1., 2000. Mini livestock production in Nigeria: The Present and the Future. 'Tn' Proceedings of $5^{\text {th }}$ Annual conference of Animal Science Association of Nigeria. September, 19 $-22,2000$, Port Harcourt, Nigeria. Pp. 101 102

Egege, S. C., 1994. Rumen ingesta as feed supplement for rabbits sensory properties of meat from rabbits fed rumen ingesta J. Agric. Technol. $2(2): 65-75$.

Ekpenyong, T. E., 1984. Effect of feeding poultry mash on growth performance of weaner rabbit, $\mathrm{J}$. Appl. Rabbit Res. 6(1) 21:21-22.

Fieiding, D., 1991. Rabbits Macmillan Education Ltd. London and Basingstoke.

Ghol, B., 1981. Tropical Feeds: Feed Information Summaries and Nutrient Value. FAO. Animal Production Series, FAO, Rome, Italy. Pp. 391 405.

Harris, D. J. Cheeke, P. R. and Patton, N. M., 1983. Feed preferences and growth performanco $u$ rabbits fed pelleted versus unpelleted wiets. J. Appl. Rabbit Res, 6:15-17

Ibeawuchi, J. A and Gbue, E. G., 1995. The effect on graded levels of dried bovine rumei content in the diet of weanling rabbits on their performance 
characteristics and carcass quality. Paper presented at the $20^{\text {th }}$ Annual Conference of

Nigerian Society for Animal Production, $26^{\text {th }}$ $30^{\text {th }}$ March, 1995, Federal University of Technology, Minna, Nigeria.

Kennedy, L. G and Hershberger, T. V, 1974. Protein quality for non-ruminant herbivore $J$. Anim. Sci. 39: $506-511$.

McNitt, J. I., 1980. The rabbit as a domestic meat source in Malawi. J. Appl. Rabbit Res. 3: 5 10

Olumeyan, B. Afolayan, S. B. and Bawa, G. S., 1995. Effect of graded levels of dried rumen ingesta on the performance of growing rabbits Fed concentrate diets. Paper presented at the $20^{\text {th }}$ Annual National Conference of Nigeria Society for Animal Production, 26 $6^{\text {th }}-30^{\text {th }}$ March, 1995. Federal University of. Technology, Minna, Nigeria.

Omole, T. A., 1982. Influence of level of dietary protein supplementation on performance of growing rabbits. J. Appl. Rabit Res. 4:3-4.

Owen, J. E., 1981. Rabbit meat for developing countries. World Anim. Rev, 39:2 - 11.
Pauzenga, U., 1985. Feeding parent stock. ZOOTECH International, pp. $22-25$.

Rao, D. R., Sunke, G. R., Johnson, W. M. and Chen, C. P., 1978. Effect of weaning and slaughter ages on rabbit meat production II. Carcass quality and composition. J. Anim. Sci. 46:578 - 583.

Spedding, C. R. W. Walsingham, J. M. and Large, R. V., 1976. The effect of reproductive rate on the feed conversion efficiency of meat producing animals. World Rev. Anim. Prod. 12:43 - 49 .

Spreadbury, D., 1974. Protein and amino acid requirement of the growing meat rabbit. Proceeding of the Nutrition Society $33 \div 5564$.

Spreadbury, D., 1978. A study of the protein and amino acid requirement of growing New Zeatand White rabbit with emphasis on lysine and the sulphur containing amino acids. Brit. J. Nutr.-39: 601 615.

Steel, R. G. D. and Torrie, J. H., 1980. Principles and Procedure of Statistics. A Biometrical Approach. $2^{\text {nd }}$ ed. McGraw Hill Book Co. New York, USA. P. 688. 